\title{
PENGARUH PENERBITAN SUKUK TERHADAP RETURN ON ASSETS EMITEN DI BURSA EFEK INDONESIA ${ }^{1}$
}

\author{
Fathaniadina Fakhrana \\ Mahasiswa Program Studi S1 Ekonomi Islam-Fakultas Ekonomi dan Bisnis-Universitas Airlangga \\ Email: fathaniadina.fakhrana-13@feb.unair.ac.id \\ Imron Mawardi \\ Departemen Ekonomi Syariah-Fakultas Ekonomi dan Bisnis-Universitas Airlangga \\ Email: ronmawardi@feb.unair.ac.id
}

\begin{abstract}
ABTRACT:
This study aims to determine the issuance effect of sukuk on the financial performance issuer in Indonesia Stock Exchange during 2011 to 2015. The independen variable that used is Sukuk to Equity Ratio and Sukuk to Liability Ratio. The dependen variable is Return on Assets. The analysis technique that used is panel data regression with Econometric Views (EViews) 8.0 as statistical analysis software. The samples are 10 sukuk issuers in Bursa Efek Indonesia. The results of this study showed that Sukuk to Equity Ratio and Sukuk to Liability Ratio there was a possitive and significant effect to Return on Assets.
\end{abstract}

Keywords: Sukuk to Equity Ratio, Sukuk to Liability Ratio, Return on Assets.

\section{PENDAHULUAN}

\section{Latar Belakang}

Kevangan berbasis syariah dewasa ini telah berkembang dan diterima secara luas di dunia serta telah menjadi alternatif baik bagi pasar modal. Mekanisme dalam pasar modal ada yang secara konvensional maupun syariah. Pasar modal syariah menghindari adanya kandungan haram dan untuk mengakomodir kebutuhan sesuai dengan prinsip syariah. Berbagai instrumen atau produk investasi yang sekarang berkembang di pasar modal syariah salah satunya yang dikenal adalah sukuk.

$$
\text { Sukuk menurut Ryandono }
$$

(2009:350), merupakan surat berharga yang berisi kontrak (akad) pembiayaan berdasarkan prinsip syariah yang mewajibkan pihak penerbit membayar pendapatan berupa bagi hasil, fee atau margin selama masa akad dan mengembalikan dana investasi saat jatuh tempo kepada investor.

Di Indonesia sukuk diterbitkan oleh korporasi dan pemerintah. Sejak pertamakali diterbitkan, keduanya dapat dikatakan mengalami peningkatan dari tahun ke tahun. Khususnya untuk sukuk korporasi yang semakin banyak dikenal oleh berbagai perusahaan, sebagai peluang dan alternatif kebutuhan pendanaan. Berikut grafik perkembangan sukuk tahun 2010-2015.

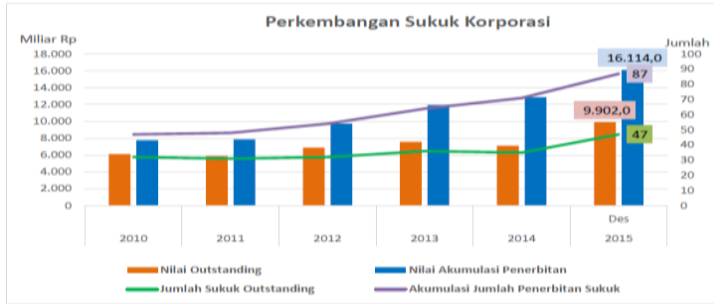

Sumber: www.ojk.go.id

Gambar 1.

Grafik Perkembangan Sukuk Korporasi Sukuk korporasi memiliki potensi pertumbuhan yang besar di Indonesia,

1 Jurnal ini merupakan bagian dari skripsi yang ditulis oleh Fathaniadina Fakhrana, NIM : 041311433176 yang diuji pada 02 Juni 2017 
Fakhrana, et al/Jurnal Ekonomi Syariah Teori dan Terapan Vol. 5 No. 5 Mei 2018: 405-419; PENGARUH PENERBITAN SUKUK TERHADAP RETURN ON ASSETS EMITEN DI BURSA EFEK INDONESIA.

pertumbuhan sukuk ini memberi sinyal bahwa instrumen keuangan syariah bisa menjadi penyongkong kebutuhan pendanaan perusahaan untuk saat ini dan masa mendatang.

Perusahaan dalam mencapai tujuan yang diinginkannya membutuhkan sumber pembiayaan yang dapat diperoleh melalui pembiayaan internal dan eksternal (Darsono dan Hestiningrum, 2012). Dalam pengambilan keputusan pendanaan perusahaan cenderung memilih untuk menambah sumber dana dengan biaya paling rendah melalui pembiayaan eksternal berupa hutang.

Dalam pengelolaan perusahaan dengan cara Islami tentu diharapkan dapat memberikan dampak positif selain mencari keuntungan, pendanaan yang diperoleh dari hutang dengan bunga yang bersifat tetap jika salah dalam mengelola bisa mengurangi keuntungan bahkan menghambat pertumbuhan perusahaan. Pada penelitian ini hutang dihitung dengan menggunakan beberapa proksi atau pendekatan secara islami terhadap rasio yang mengukur proporsi penggunaan hutang dalam membiayai kegiatan operasional perusahaan melalui instrumen sukuk, yaitu Sukuk to Equity Ratio dan Sukuk to Liability Ratio.

Hal ini mencerminkan semakin tinggi proporsi hutang atau kewajiban yang dibiayai menggunakan instrumen secara islami sesuai dengan prinsip syariah. Dengan kata lain, kewajiban yang menggunakan dengan sistem bunga yang merupakan salah satu perwujudan dari riba akan semakin kecil sehingga dapat meningkatkan keberkahan.

Melalui keputusan pendanaan perusahaan ini akan mempengaruhi kondisi struktur modal yang sangat penting bagi perusahaan untuk memaksimalkan nilai perusahaan. Selain itu struktur modal berhubungan dengan profitabilitas, dimana perubahan struktur modal diharapkan dapat meningkatkan kinerja operasional perusahaan sehingga menghasilkan profitabilitas bagi perusahaan. Menurut Sudana (2005:25) rasio profitabilitas dapat diukur salah satunya dengan return on assets. Komposisi hutang dan ekuitas yang tidak optimal akan mengurangi profitabilitas serta sebaliknya. Semakin tinggi tingkat profitabilitas suatu perusahaan, maka dapat dikatakan semakin profitable yang mengindikasikan semakin efisien kinerja sebuah perusahaan dan meningkatkan nilai perusahaan tersebut (Copeland,dkk., 1994).

\section{RUMUSAN MASALAH}

Melalui latar belakang di atas maka rumusan masalah yang dapat dibuat adalah:

1. Apakah Sukuk to Equity Ratio secara parsial berpengaruh terhadap Return on Assets emiten penerbit sukuk di Bursa Efek Indonesia tahun 2011-2015?

2. Apakah Sukuk to Liability Ratio secara parsial berpengaruh terhadap Return on Assets emiten penerbit sukuk di Bursa Efek Indonesia tahun 2011-2015? 
Fakhrana, et al/Jurnal Ekonomi Syariah Teori dan Terapan Vol. 5 No. 5 Mei 2018: 405-419; PENGARUH PENERBITAN SUKUK TERHADAP RETURN ON ASSETS EMITEN DI BURSA EFEK INDONESIA.

3. Apakah Sukuk to Equity Ratio dan Sukuk to Liability Ratio secara simultan berpengaruh terhadap Return on Assets emiten penerbit sukuk di Bursa Efek Indonesia tahun 2011-2015?

\section{TUJUAN}

1. Untuk mengetahui secara parsial pengaruh sukuk to Equity Ratio terhadap Return on Assets emiten penerbit sukuk di Bursa Efek Indonesia tahun 2011-2015.

2. Untuk mengetahui secara parsial pengaruh Sukuk to Liability Ratio terhadap Return on Assets emiten penerbit sukuk di Bursa Efek Indonesia tahun 2011-2015.

3. Untuk mengetahui secara simultan pengaruh Sukuk to Equity Ratio dan Sukuk to Liability Ratio terhadap Return on Asset emiten penerbit sukuk di Bursa Efek Indonesia tahun 2011-2015.

\section{LANDASAN TEORI}

Investasi adalah bagian dari konsep muamalah. Menurut Ryandono (2008:67) bahwa berbagai definisi dari investasi mengandung tiga unsur yang sama. Pertama, pengeluaran atau pengorbanan sesuatu (sumber daya) pada saaat sekarang yang bersifat pasti. Kedua, ketidakpastian mengenai hasil (risiko) dan ketiga, ketidakpastian atau pengembalian di masa datang.

Namun pada hakikatnya secara filosofis investasi berdasarkan konsep Islam menurut Kertonegoro (1996) dalam Sutedi Adrian (2011:126) sesungguhnya tidak berbeda dengan konsep konvensional. Investasi yang islami adalah pengorbanan sumber daya pada masa sekarang untuk mendapatkan hasil yang pasti, dengan harapan memperoleh hasil yang lebih besar di masa yang akan datang, baik langsung dan tidak langsung seraya tetap berpijak pada prinsip syariah secara menyeluruh atau kaffah (Ryandono, 2008:70).

Teori pada pecking order yang menyatakan bahwa "keputusan pendanaan akan mengikuti suatu hierarki dimana sumber pendanaan internal lebih diutamakan dibandingkan pendanaan dari sumber eksternal" (Darsono dan Hestiningrum, 2012). Hal demikian apabila pendanaan eksternal diperlukan, maka perusahaan akan memilih dana sekuritas yang paling aman yaitu hutang yang paling rendah risiko nya.

Pasar modal sesuai dengan Undang-Undang Nomor 8 Tahun 1995 didefinisikan sebagai kegiatan yang bersangkutan dengan penawaran umum dan perdagangan efek, perusahaan publik yang berkaitan dengan perdagangan efek yang diterbitkannya, serta lembaga dan profesi yag berkaitan dengan efek.

Pasar modal memiliki peran penting bagi perekonomian suatu negara, karena satu, sebagai sarana pendanaan bagi perusahaan dari masyarakat pemodal (investor). Kedua, pasar modal menjadi sarana untuk berinvestasi dimana masyarakat dapat menempatkan dana yang dimiliki sesuai karakteristik keuntungan dan risiko masing-masing. (www.idx.co.id) 
Fakhrana, et al/Jurnal Ekonomi Syariah Teori dan Terapan Vol. 5 No. 5 Mei 2018: 405-419; PENGARUH PENERBITAN SUKUK TERHADAP RETURN ON ASSETS EMITEN DI BURSA EFEK INDONESIA.

Hutang dalam islam bukan haram namun perlu diminimalkan. Sehingga penggunaan hutang dapat diganti dengan instrumen sukuk. Menurut Dewan Syariah Nasional (DSN) sukuk disamakan dengan obligasi syariah, dalam fatwa No.32/DSN-MUI/IX/2002.

Penerbitan sukuk di bursa efek membutuhkan tiga tahapan utama yaitu tahap persiapan penerbitan sukuk, proses di Badan Pengawas Pasar Modal (Bapepam), penawaran umum dan proses pencatatan dan perdagangan di bursa efek (Ryandono, 2009:279).

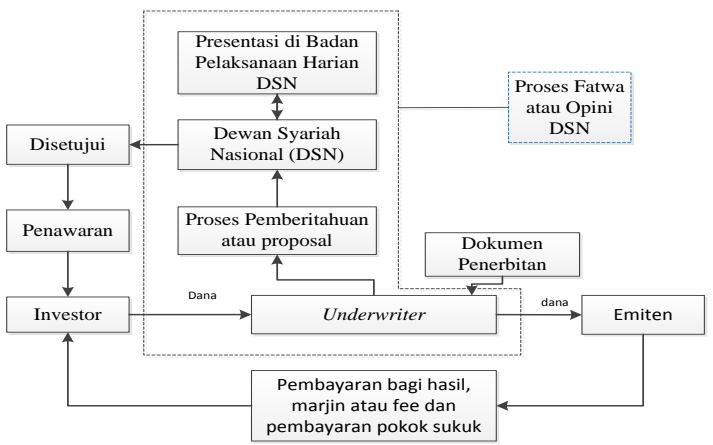

Sumber : Ryandono, M.Nafik Hadi. 2009. Bursa Efek dan Investasi Syariah. Jakarta:Serambi

Gambar 2

Proses Penerbitan Sukuk

Pada proses persiapan, emiten harus mempersiapkan dokumen-dokumen utama. Selain itu juga dibutuhkan dokumen penunjang registrasi ke Bapepam. Setelah proses persiapan, selanjutnya adalah pengajuan ke Bapepam. Pada tahap ini, Bapepam meneliti dan menelaah pernyataan pendaftaran yang disampikan perusahaan. Telaah itu ditekankan pada prinsip kelengkapan dan unsur keterbukaan informasi (full disclosure). Dan tahap selanjutnya adalah pengeluaran pernyataan pendaftaran efektif atau tidak. Tahap selanjutnya adalah proses penawaran umum sukuk. Pada tahap ini dilakukan percetakan prospektus, dokumen-dokumen yang berkaitan dengan bursa, dan sertifikat sukuk. Prospektus singkat selambat-lambatnya dikeluarkan tiga hari kerja sebelum penawaran umum dan diiklankan pada sekurang-kurangnya satu surat kabar yang terbit secara nasional dan bahasa Indoneia. Prospektus dan Formulir Pemesanan Pembelian Sukuk (FPPS) harus tersedia satu hari sebelum penawaran umum. Penawaran umum sukuk harus dilaksanakan minimal tiga hari kerja berturut-turut dan penutupan penawaran umum tidak lebih dari 15 hari kerja sejak tanggal efektif keluar dari Bapepam. Setelah sukuk diperdagangkan di pasar perdana, maka proses selanjutnya adalah proses pencatatan di bursa dan setelah itu akan diperdagangkan secara sekunder di lantai bursa (Ryandono, 2009:282).

Di Indonesia jenis sukuk yang ada dan sering digunakan adalah sebagai berikut: (www.ojk.go.id)

1. Sukuk Mudharabah terdapat dalam fatwa No.33/DSN-MUI/IX/2002. Menurut Ryandono (2009:253) adalah seperti pengertian dari sukuk dengan mewajibkan pihak penerbit sukuk membayar pendapatan kepada pemegang sukuk berupa bagi hasil dari hasil pengelolaan dana yang telah disetorkan pemilik dana serta membayar 
Fakhrana, et al/Jurnal Ekonomi Syariah Teori dan Terapan Vol. 5 No. 5 Mei 2018: 405-419; PENGARUH PENERBITAN SUKUK TERHADAP RETURN ON ASSETS EMITEN DI BURSA EFEK INDONESIA.

kembali dana pokok sukuk pada saat jatuh tempo. Struktur sukuk mudharabah sebagai berikut:

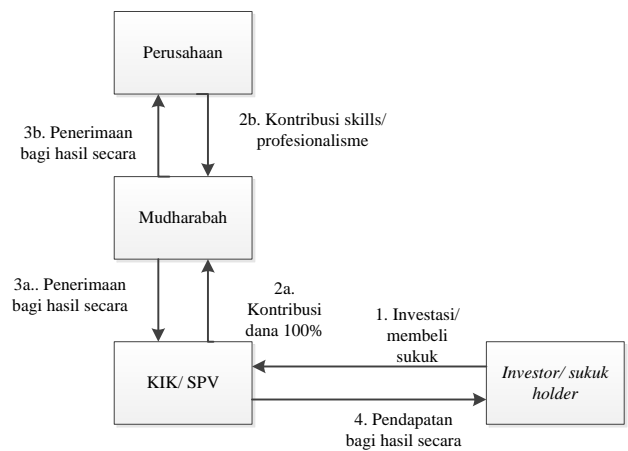

Sumber : Ryandono, M.Nafik Hadi. 2009. Bursa Efek dan Investasi Syariah. Jakarta:Serambi

Gambar 3.

Struktur Sukuk Mudharabah

Pihak yang terlibat dalam sukuk mudharabah adalah investor (shahibul maal), Special Purpose Vehicle (SPV), atau Kontrak Investasi Kolektif (KIK) dan perusahaan (emiten atau mudharib). Sukuk Mudharabah yang diterbitkan oleh perusahaan dibeli oleh investor setelah mempertimbangkan prospektus yang ada dan informasi-informasi lain yang relevan. Dengan seluruh modal dari investor yang terkumpul pada SPV diberikan kepada mudharib atau emiten. Bagi hasil antara SPV dan emiten berdasarkan nisbah yang disepakati.

Pendapatan bagi hasil yang diterima oleh SPV secara periodik sesuai nisbahnya, lalu SPV akan membagikan kepada pemegang sukuk mudharabah sesuai komposisi masing-masing sukuk secara periodik. Kemudian pokok sukuk akan dibayar kembali sebesar nilai penyertaan masing-masing investor pada saat jatuh tempo.

2. Sukuk ljarah berdasarkan fatwa DSN dan MUI terkait SBSN ljarah. Pengertian dari sukuk ijarah adalah seperti pengertian sukuk dengan mewajibkan penerbit sukuk membayar pendapatan kepada pemegang sukuk berupa fee dari hasil penyewaan aset serta membayar kembali dana pokok sukuk pada saat jatuh tempo (Ryandono, 2009:256). Berikut struktur sukuk ijarah.

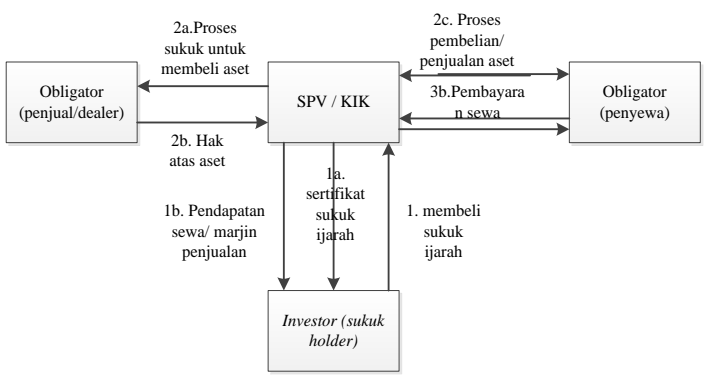

Sumber : Ryandono, M.Nafik Hadi 2009. Bursa Efek dan Investasi Syariah. Jakarta:Serambi

Gambar 4.

Struktur Sukuk ljarah

Pada sukuk ijarah terdapat tiga pihak yang terlibat dalam akad-akadnya. Akad investasi yaitu antara investor dan pihak SPV/ Kontrak Investasi Kolektif. Akad jual beli antara pihak SPV/KIK dan pihak supplier atau penjual asset. Dan akad sewa (ijarah) atau jual beli antara SPV/KIK dan perusahaan pembeli atau penyewa asset. (Ryandono,2009)

Penerapan prinsip syariah melalui investasi syariah adalah sesuatu yang relatif pasti dalam kaitan penyaringan kelayakan usaha dan jenis investasi. 
Fakhrana, et al/Jurnal Ekonomi Syariah Teori dan Terapan Vol. 5 No. 5 Mei 2018: 405-419; PENGARUH PENERBITAN SUKUK TERHADAP RETURN ON ASSETS EMITEN DI BURSA EFEK INDONESIA.

Penyaringan kelayakan usaha biasanya lebih sering diutamakan pada besarnya hutang perusahaan yang berbasis bunga dimana secara konvensional dapat diukur dengan salah satu rasio yaitu debt to equity ratio, seperti Kasmir (2010:156) menyatakan bahwa debt to equity ratio merupakan rasio yang digunakan untuk menilai utang dan ekuitas. Kini dalam syariah yang berkaitan dengan hutang berbasis bunga adalah penekanan pada hutang yang tidak berbasis bunga dengan instrumen penggunaan sukuk yang indikator nya sukuk to equity ratio.

$$
\text { Sukuk to Equity Ratio }
$$

mencerminkan dalam mengukur proporsi dana yang bersumber dari sukuk pada ekuitas perusahaan. Semakin tinggi rasio ini maka semakin tinggi pula proporsi ekuitas perusahaan yang dibiayai menggunakan instrumen yang sesuai dengan prinsip syariah (Putri, 2015). Sehingga sukuk to equity ratio dihitung dengan menggunakan rumus berikut:

Sukuk to Equity Ratio $=\frac{\text { Sukuk }}{\text { Total Equity }}$

Penggunaan hutang atau indikator sukuk dalam syariah pada suatu perusahaan dapat meningkatkan profitabilitas yang akan menaikkan nilai suatu perusahaan. Profitabilitas merupakan kemampuan perusahaan dalam memperoleh pendapatan atau laba dari usahanya dan daya tarik bagi pemilik perusahaan.

Menurut Sudana (2005:25) rasio profitabilitas dapat diukur salah satunya dengan return on assets. Nilai return on assets sebagai hasil kinerja perusahaan yang dipengaruhi oleh perubahan struktur modal akibat penggunaaan instrumen sukuk ini. Rasio return on assets dapat dihitung dengan beberapa rumus sebagai berikut para ahli yaitu menurut Tunggal (2008:350)

$$
\mathrm{ROA}=\frac{\text { Net Profit After } T a x}{\text { Total Asset }}
$$

Dengan demikian adanya pengaruh yang berkesinambungan antara sukuk to equity ratio terhadap return on assets. Karena menurut Herlambang dalam Putri (2015) di dalam nilai sukuk to equity ratio merupakan underlying pada nilai return on assets.

Indikator Sukuk to Liability Ratio mencerminkan perbandingan sukuk terhadap total kewajiban yang menjadi kewajiban dari perusahaan. Semakin besar rasio ini menunjukkan porsi sukuk atau kewajiban yang dibiayai menggunakan instrumen sesuai dengan prinsip syariah semakin besar. Sehingga rasio ini dapat dihitung menggunakan rumus sebagai berikut:

Sukuk to Liability Ratio $=\frac{\text { Sukuk }}{\text { Total Liability }}$

$$
\text { Pelaksanaan syariah dalam }
$$
instrumen sukuk semestinya memberikan dampak positif terhadap pendapatan perusahaan yang nantinya akan meningkatkan nilai perusahaan (Baynuny, 2013). Menurut Kamir (2010:196) nilai perusahaan tentunya dipengaruhi oleh faktor profitabilitas. Profitabilitas sangatlah penting bagi perusahaan karena menunjukkan perusahaan ini mempunyai 
Fakhrana, et al/Jurnal Ekonomi Syariah Teori dan Terapan Vol. 5 No. 5 Mei 2018: 405-419; PENGARUH PENERBITAN SUKUK TERHADAP RETURN ON ASSETS EMITEN DI BURSA EFEK INDONESIA.

prospek yang bagus atau tidak di masa yang akan datang. Seperti yang dijelaskan sebelumnya dalam mengukur profitabilitas salah satunya menggunakan rasio return on assets. Dengan demikian semakin tinggi sukuk to liability ratio ini maka akan semakin tinggi pula proporsi kewajiban yang dibiayai menggunakan instrumen sesuai dengan prinsip syariah.

\section{HIPOTESIS PENELITIAN}

Ada tiga hipotesis dalam penelitian ini yang dapat dijelaskan sebagai berikut:

1. Sukuk to Equity Ratio secara parsial berpengaruh terhadap Return on Assets emiten penerbit sukuk yang terdaftar di Bursa Efek Indonesia tahun 2011-2015.

2. Sukuk to Liability Ratio secara parsial berpengaruh terhadap Return on Assets emiten penerbit sukuk yang terdaftar di Bursa Efek Indonesia tahun 2011-2015.

3. Sukuk to Equity Ratio dan Sukuk to Liability Ratio secara simultan berpengaruh terhadap Return on Assets emiten penerbit sukuk yang terdaftar di Bursa Efek Indonesia tahun 2011-2015.

\section{METODE PENELITIAN}

\section{Pendekatan Penelitian}

Pendekatan yang digunakan dalam penelitian ini adalah penelitian kuantitatif dengan metode analisis regresi data panel. Metode regresi data panel digunakan untuk mengetahui apakah ada pengaruh yang signifikan dari variable independen yang jumlahnya lebih dari satu terhadap variable dependen, data ini merupakan gabungan dari time series dan cross section.

\section{Definisi Operasional Variabel}

1. Sukuk to Equity Ratio diperoleh dari perbandingan besarnya proporsi dana yang bersumber dari sukuk pada ekuitas perusahaan.

2. Sukuk to Liability Ratio diperoleh dari besarnya nilai sukuk dibagi total liability emiten penerbit sukuk yang menjadi kewajiban dari emiten penerbit sukuk tersebut

3. Return on Assets diperoleh dari besarnya nilai net profit after tax dibagi total assets (Tunggal,2008:350).

\section{Jenis dan Sumber Data}

Data yang digunakan dalam penelitian ini adalah data sekunder berupa data yang diperoleh dari Bursa Efek Indonesia berupa laporan keuangan tahunan emiten penerbit sukuk tahun 2011-2015, data nilai outstanding sukuk di Otoritas Jasa Keuangan tahun 2011-2015, penelitian terdahulu, dan artikel.

\section{Populasi dan Sampel}

Populasi dalam penelitian ini adalah emiten penerbit sukuk yang terdaftar di Bursa Efek Indonesia. Pengambilan sampel dalam penelitian ini dilakukan dengan purposive sampling, dengan kriteria perusahaan sampel tercatat sebagai emiten yang menerbitkan sukuk dan mengumumkan laporan keuangan selama tahun 20112015.

\section{Teknik Analisis Data}


Fakhrana, et al/Jurnal Ekonomi Syariah Teori dan Terapan Vol. 5 No. 5 Mei 2018: 405-419; PENGARUH PENERBITAN SUKUK TERHADAP RETURN ON ASSETS EMITEN DI BURSA EFEK INDONESIA.

\section{Estimasi Regresi Data Panel}

Menurut Grenee (1991:481) dalam mengestimasi data panel terdapat tiga pendekatan yang biasa dilakukan, yaitu model Common EffectModel (CEM), Fixed Effect Model (FEM), dan Random Effect Model (REM).

1. Common Effect Model (CEM)

Teknik paling sederhana untuk mengestimasi data panel adalah dengan mengkombinasikan data time series dan cross section. Maka dapat menggunakan metode OLS untuk mengestimasi model data panel (Widarjono, 2013:355).

2. Fixed Effect Model (FEM)

Teknik model fixed effect adalah teknik mengestimasi data panel dengan menggunakan variabel dummy. Model ini didasarkan adanya perbedaan intersep antara subjek penelitian namun intersepnya sama antar waktu (time invariant). Disamping itu, model ini juga mengasumsikan bahwa koefisien regresi (slope) adalah tetap untuk antar subjek penelitian dan antar waktu (Widarjono, 2013:356).

3. Random Effect Model (REM) Model ini mengestimasi data panel dimana variabel gangguan mungkin saling berhubungan antar waktu dan antar individu dan diasumsikan setiap subjek penelitian memiliki perbedaan intersep (Widarjono, 2013:359). Menurut Gujarati dan Dawn
(2013:250) model ini memperhitungkan error dari cross section dan time series.

\section{Pemilihan Model Regresi Data Panel}

Untuk memilih model mana yang paling tepat digunakan untuk pengolahan data panel, maka terdapat beberapa pengujian yang dapat dilakukan yaitu uji $F$ statistic dan uji Hausman.

1. Chow Test

Pengujian untuk memilih apakah model yang digunakan menggunakan common effect atau fixed effect (Widarjono,2013:362).

2. Hausman Test

Pengujian statistik sebagai dasar pertimbangan dalam memilih apakah menggunakan model fixed effect atau model random effect.

\section{Uji Hipotesis}

\section{Uji Parsial (Uji t)}

Uji † merupakan pengujian terhadap variabel-variabel bebas/independen secara parsial (individu) yang ditunjukkan untuk melihat signifikan dan pengaruh terhadap variabel dependen, dengan asumsi variabel independennya dianggap konstan.

\section{Uji Simultan (Uji F)}

Uji F digunakan untuk melihat apakah ada pengaruh variabel independen secara bersama-sama terhadap variabel dependen. Uji $F$ bisa dijelaskan dengan menggunakan varian lanalysis of variance = ANOVA). 
Fakhrana, et al/Jurnal Ekonomi Syariah Teori dan Terapan Vol. 5 No. 5 Mei 2018: 405-419; PENGARUH PENERBITAN SUKUK TERHADAP RETURN ON ASSETS EMITEN DI BURSA EFEK INDONESIA.

\section{Analisis Koefisien Determinasi $\left(\mathbf{R}^{2}\right)$}

Koefisien determinasi

dimaksudkan untuk mengetahui tingkat ketepatan paling baik dalam menganalisis regresi, dimana hal yang ditunjukkan oleh besarnya koefisien determinasi $\left(R^{2}\right)$ antara nol (0), dan 1. Koefisien determinasi dapat dicari dengan rumus :

$\mathrm{R}^{2}=\mathrm{ESS}=1$, nilai $\mathrm{R}^{2}$ besarnya antara

$0-1\left(0 \leq R^{2} \leq 1\right)$

Koefisien determinasi $\left(R^{2}\right)$ nol, berarti variabel independen sama sekali tidak berpengaruh terhadap variabel dependen. Apabila koefisien determinasi $\left(R^{2}\right)$ mendekati satu, maka dapat dikatakan bahwa variabel independen berpengaruh terhadap variabel dependen.

\section{HASIL DAN PEMBAHASAN}

\section{StatistikDeskriptif}

Tabel 1.

Statistik Deskriptif Sukuk to Equity Ratio, Sukuk to Liability Ratio, dan Return on

\begin{tabular}{|c|c|c|c|}
\hline \multicolumn{4}{|c|}{ Assets } \\
\hline & SER? & SLR? & ROA? \\
\hline Mean & 0.107071 & 0.144226 & 0.031184 \\
\hline Median & 0.075442 & 0.032369 & 0.025412 \\
\hline Maximum & 0.814974 & 4.665993 & 1.851710 \\
\hline Minimum & -0.474942 & 0.004699 & -0.649154 \\
\hline Std. Dev. & 0.200655 & 0.654661 & 0.308135 \\
\hline
\end{tabular}

\section{Pemilihan Model Regresi Data Panel}

Tabel 2.

Hasil Uji Model Menggunakan Haussman Test

Correlated Random Effects - Hausman Test

Pool: Untitled

Test cross-section random effects

\begin{tabular}{l}
\hline \hline Test Summary \\
\end{tabular}

38.90808

$$
\begin{array}{lrrr}
\text { Cross-section random } & 8 & 2 & 0.0000
\end{array}
$$

Pada perhitungan statistik yang telah dilakukan diatas, dapat dilihat bahwa nilai probabilitas pada test cross section random effect memperlihatkan angka bernilai 0,0000 yang berarti signifikan dengan tingkat signifikansi $95 \%$ ( $a=5 \%$ ) dan menggunakan distribusi ChiSquare (Gujarati,2013).

Sehingga bisa diambil keputusan dalam penelitian ini pada pengujian Hausmann test yaitu bahwa yang ditolak adalah Ho ( $p$-value $<0,05)$. Dengan demikian model pilihan yang digunakan pada penelitian ini yaitu FEM.

Tabel 3.

Hasil Regresi Metode Fixed Effect Model (FEM)

Dependent Variable: ROA?

Method: Panel Least Squares

Date: 05/23/17 Time: 12:01

Sample: 20112015

Included observations: 5

Cross-sections included: 10

Total pool (balanced) observations: 50

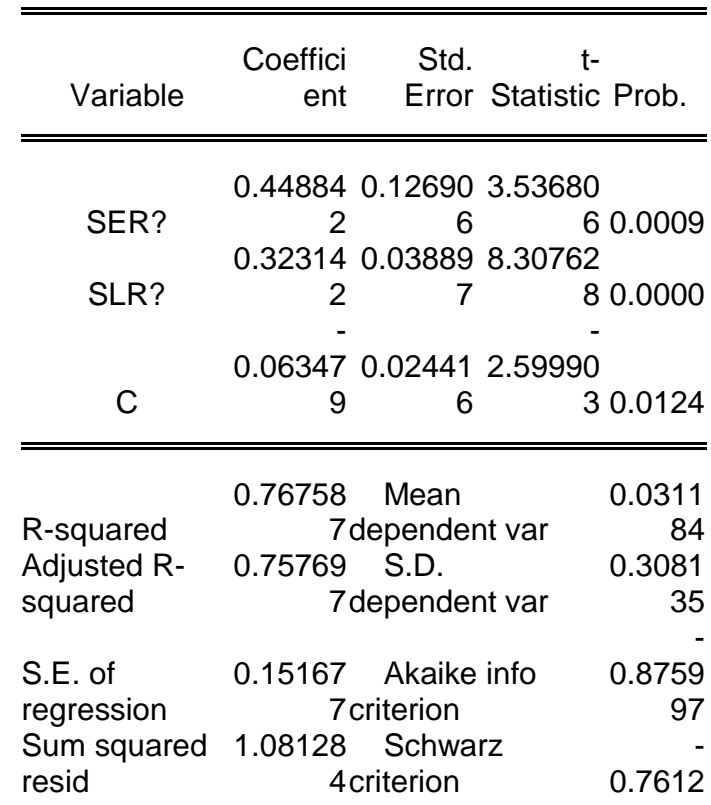


Fakhrana, et al/Jurnal Ekonomi Syariah Teori dan Terapan Vol. 5 No. 5 Mei 2018: 405-419; PENGARUH PENERBITAN SUKUK TERHADAP RETURN ON ASSETS EMITEN DI BURSA EFEK INDONESIA.

\begin{tabular}{|c|c|c|}
\hline \multirow{3}{*}{ Log likelihood } & 24.8999 Hannan-Quinn & 0.8323 \\
\hline & 3criter. & 11 \\
\hline & 77.6130 Durbin-Watson & 2.0651 \\
\hline F-statistic & 4 stat & 12 \\
\hline Prob(F- & 0.00000 & \\
\hline statistic) & 0 & \\
\hline
\end{tabular}

Tabel diatas menunjukkan hasil dari perhitungan Fixed Effect Model (FEM) yang menggunakan software Eviews 8.0 dapat diketahui bahwa nilai R-square sebesar 0.767587 . Artinya, bahwa variabel independen dapat menjelaskan variabilitas dependen (return on assets) sebesar $76,75 \%$, sedangkan sisanya dijelaskan oleh variabel lain yang tidak diteliti oleh peneliti atau tidak dimasukkan ke dalam penelitian ini.

\section{Uji Hipotesis}

\section{Uji Simultan (F-test)}

Tabel 4.

Hasil Uji Simultan (F-test)

Berdasarkan pada Tabel diatas, dapat dilihat bahwa nilai F-hitung adalah sebesar 77.61304 dan hasil nilai probability F-statistic adalah 0,000000 kurang dari a $(0,05)$ artinya $\mathrm{H}_{0}$ ditolak dan $\mathrm{H}_{1}$ diterima, dapat disimpulkan bahwa sukuk to equity ratio dan sukuk to liability ratio secara simultan berpengaruh signifikan terhadap return on assets emiten penerbit sukuk di Bursa Efek Indonesia tahun 2011-2015.

\section{Uji Parsial (t-test)}

Tabel 5.

Hasil Estimasi Uji $†$

\begin{tabular}{|l|l|l|l|}
\hline Variabel & Probability & $\begin{array}{l}\text { Loss } \\
\text { (a) }\end{array}$ & Keterangan \\
\hline SER & 0.0009 & 0.05 & $\begin{array}{l}\text { Nilai prob < } \\
\text { (a): } \\
\text { ditolak }\end{array}$ \\
\hline
\end{tabular}

\begin{tabular}{|l|l|l|l|}
\hline SLR & 0.0000 & & Nilai prob < \\
& & (a): $\quad \mathrm{H}_{0}$ \\
ditolak
\end{tabular}

Berdasarkan tabel diatas dapat disimpulkan variabel SER secara parsial berpengaruh signifikan terhadap return on assets emiten penerbit sukuk di Bursa Efek Indonesia. Dan variabel SLR secara parsial berpengaruh signifikan terhadap return on assets emiten penerbit sukuk di Bursa Efek Indonesia.

\section{Analisis Koefisien Determinasi $\left(\mathbf{R}^{2}\right)$}

Tabel 6. Hasil Estimasi Uji R2

\begin{tabular}{|c|c|c|}
\hline $\mathbf{R}^{2}$ & Adjusted $\mathbf{R}^{2}$ & Interpretasi Hasil \\
\hline 0.767587 & 0.757697 & $\begin{array}{c}\text { Nilai } \mathrm{R}^{2} \text { tersebut } \\
\text { mengindikasikan bahwa } \\
\text { variabel independen secara } \\
\text { simultan dapat } \\
\text { menjelaskan variabel } \\
\text { dependen sebesar 76,75\% }\end{array}$ \\
\hline \multicolumn{2}{|c|}{ Pada Tabel diatas, koefisien }
\end{tabular}
determinasi sebesar 0.767587 atau $76,75 \%$.

\begin{tabular}{|c|c|}
\hline F-Hitung & 77.61304 \\
\hline Prob (F-statistic) & 0.000000 \\
\hline
\end{tabular}

Angka tersebut menunjukkan bahwa variabel return on assets dapat dijelaskan oleh variabel sukuk to equity ratio dan sukuk to liability ratio sebesar $76,75 \%$. Besar sukuk to equity ratio dan sukuk to liability ratio terhadap return on assets emiten penerbit sukuk di Bursa Efek Indonesia tahun 2011-2015 yaitu sebesar 76,75\% dan sisanya $23,25 \%$ dipengaruhi oleh faktorfaktor lain yang tidak dimasukkan dalam penelitian.

Hasil analisis menunjukkan bahwa pengaruh pengaruh sukuk to equity ratio dan sukuk to liability ratio secara simultan terhadap return on assets emiten penerbit 
Fakhrana, et al/Jurnal Ekonomi Syariah Teori dan Terapan Vol. 5 No. 5 Mei 2018: 405-419; PENGARUH PENERBITAN SUKUK TERHADAP RETURN ON ASSETS EMITEN DI BURSA EFEK INDONESIA.

sukuk di Bursa Efek Indonesia dapat dilihat dari hasil uji hipotesis melalui uji $\mathrm{F}$ dalam Tabel 4. yang menyatakan bahwa sukuk to equity ratio dan sukuk to liability ratio berpengaruh signifikan terhadap return on assets emiten penerbit sukuk di Bursa Efek Indonesia tahun 2011-2015.

Sesuai dengan pecking order theory yang menyatakan bahwa keputusan pendanaan akan mengikuti suatu hierarki dimana apabila pendanaan eksternal diperlukan, maka perusahaan akan memilih dana sekuritas yang paling aman yaitu hutang yang paling rendah risiko nya melalui instrumen sukuk. Sukuk menjadi salah satu diversifikasi pendanaan untuk mencapai struktur modal optimal yang akan meningkatkan nilai perusahaan dengan nilai profitabilitas yang didapatkan. Suatu perusahaan yang profitabilitasnya tinggi, maka diyakini bahwa akan lebih dapat melangsungkan kegiatan operasional perusahaannya.

Beberapa firman Allah yang menjelaskan tentang penggunaan sukuk sebagai usaha dalam melaksanakan syariah secara kaffah adalah salah satunya pada surat Al Hasyr ayat 18

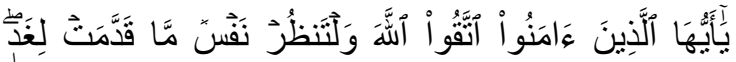

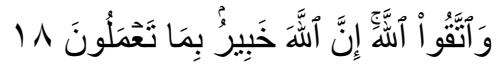

Yā ayyuhā'l-lażina āmanū ittaqūllāha waltandur nafsun mā qaddamat ligadin wattaqū allāha innallāha khabìrun bimā ta'maluna

Artinya: "Hai orang-orang yang beriman, bertakwalah kepada Allah dan hendaklah setiap diri memperhatikan apa yang telah diperbuatnya untuk hari esok (akhirat); dan bertakwalah kepada Allah, sesungguhnya Allah Maha Mengetahui apa yang kamu kerjakan".

Allah menegaskan bahwa barang siapa yang beriman dan bertakwa berarti menjalankan syariat Allah, maka Allah akan memberikan balasan berupa kemaslahatan, yaitu keberkahan dan kenikmatan dari langit dan bumi. Dengan penggunaan instrumen sukuk yang dilaksanakan secara kaffah ini maka akan mempengaruhi hasil yang diperoleh sesuai dengan haknya seta mendapatkan keberkahan

Pengaruh sukuk to equity ratio secara parsial terhadap return on assets emiten penerbit sukuk di Bursa Efek Indonesia dapat dilihat dari hasil uji hipotesis melalui uji $\dagger$ pada Tabel 5. yang menyatakan bahwa sukuk to equity ratio berpengaruh positif terhadap return on assets emiten penerbit sukuk di Bursa Efek Indonesia.

Hal ini disebabkan semakin meningkatnya investor untuk melakukan investasi pada emiten penerbit sukuk sehingga nilai sukuk to equity ratio menjadi tinggi yang kemudian akan mempengaruhi nilai perusahaan. Dalam menentukan nilai perusahaan penerbit sukuk pada penelitian ini dapat dilihat dari nilai profitabilitas yang salah satunya diukur dengan rasio return on assets.

Dengan demikian nilai sukuk to equity ratio yang tinggi akan meningkatkan return on assets suatu perusahaan karena dalam ekonomi islam nilai sukuk to equity ratio merupakan underlying dari nilai return on assets. Sesuai 
Fakhrana, et al/Jurnal Ekonomi Syariah Teori dan Terapan Vol. 5 No. 5 Mei 2018: 405-419; PENGARUH PENERBITAN SUKUK TERHADAP RETURN ON ASSETS EMITEN DI BURSA EFEK INDONESIA.

pula dengan landasan islam dalam pelaksanaan prinsip syariah melalui instrumen sukuk sebagai salah satu instrumen keuangan dimana terdapat konsekuensi untuk mewujudkan suatu kemaslahatan. Sehingga dalam pandangan ini, jika penerapan instrumen sukuk dilaksanakan dengan benar maka akan berdampak positif terhadap profitabilitas yang didapatkan perusahaan serta akan mempengaruhi nilai suatu perusahaan. Sesuai pada firman Allah SWT dalam surat Al A'raf ayat 96

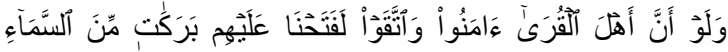

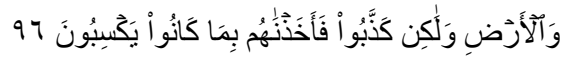

Walaw anna ahla'l-qurū āmanū wattaqaaw lafatahnā'alayhim barakātin mina'l-samā-i wal-ardhi walākin każżabū fa-akhaŻnāhum bimā kānū yaksibūna

Artinya: "Jikalau sekiranya penduduk negeri-negeri beriman dan bertakwa, pastilah Kami akan melimpahkan kepada mereka berkah dari langit dan bumi, tetapi mereka mendustakan (ayat-ayat Kami) itu, Maka Kami siksa mereka disebabkan perbuatannya".

Sehingga dalam pandangan ini sesuai dengan ayat diatas, jika penerapan instrumen sukuk dilaksanakan dengan benar maka Allah akan memberikan balasan berupa kemaslahatan, yaitu dampak positif terhadap profitabilitas yang didapatkan perusahaan serta akan mempengaruhi nilai suatu perusahaan.

Pengaruh sukuk to liability ratio secara parsial terhadap return on assets emiten penerbit sukuk di Bursa Efek Indonesia dapat dilihat dari hasil uji hipotesis melalui uji † yang menyatakan bahwa sukuk to liability ratio berpengaruh positif terhadap return on assets emiten penerbit sukuk di Bursa Efek Indonesia.

Hal ini berarti semakin tinggi sukuk to liability ratio suatu perusahaan, maka semakin tinggi nilai return on assets begitu pula sebaliknya. Perusahaan dengan rasio return on assets yang semakin meningkat menandakan bahwa kinerja yang dimiliki oleh perusahaan tersebut dapat dikatakan baik karena perusahaan akan semakin efisien dalam memanfaatkan aktiva yang dimiliki untuk menghasilkan laba (Madura, 2009:326).

Hal ini sesuai pula dengan landasan dalam islam dimana sukuk sebagai instrumen keuangan merupakan salah satu usaha dalam melaksanakan syariah secara kaffah, yaitu yang harus diyakini akan membawa kemaslahatan. Sesuai dalam firman-Nya surat An Najm ayat 39

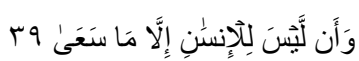

Wa an laysa li'l-insāni illā mā sa'ā

Artinya: "dan bahwasanya seorang manusia tiada memperoleh selain apa yang telah diusahakannya".

Allah SWT menegaskan bahwa siapa saja yang menjalankan syariah dengan benar akan memperoleh balasan berupa rezeki yang melimpah dan penghidupan yang lebih baik. Dengan demikian apabila instrumen sukuk ini dilaksanakan dengan benar maka semestinya akan memberikan dampak positif terhadap nilai perusahaan. 
Fakhrana, et al/Jurnal Ekonomi Syariah Teori dan Terapan Vol. 5 No. 5 Mei 2018: 405-419;

PENGARUH PENERBITAN SUKUK TERHADAP RETURN ON ASSETS EMITEN DI BURSA EFEK INDONESIA.

\section{SIMPULAN}

Berdasarkan hasil analisis dan interpretasi data yang dilakukan maka dapat diambil kesimpulan sebagai berikut:

1. Sukuk to Equity Ratio memberikan pengaruh positif dan signifikan terhadap Return on Assets emiten penerbit sukuk di Bursa Efek Indonesia pada nilai tingkat signifikansi (a) sebesar $5 \%$ atau 0,05 .

2. Sukuk to Liability Ratio memberikan pengaruh positif dan signifikan terhadap Return on Assets emiten penerbit sukuk di Bursa Efek Indonesia pada nilai tingkat signifikansi (a) sebesar $5 \%$ atau 0,05 .

3. Sukuk to Equity Ratio dan Sukuk to Liability Ratio secara simultan berpengaruh terhadap Return on Assets emiten penerbit sukuk di Bursa Efek Indonesia pada tingkat signifikansi (a) sebesar $5 \%$ atau 0,05.

4. Dari kedua variabel independen yang diteliti, yang paling berpengaruh pada Return on Assets emiten penerbit sukuk di Bursa Efek Indonesia adalah variabel Sukuk to Equity Ratio dengan koefisien sebesar 0.448842 .

\section{DAFTAR PUSTAKA}

Achsien, Iggi H. 2000. Investasi Syariah di Pasar Modal. Jakarta: Gramedia Pustaka Utama.

Akbarullah, H. Muhammad. 2011. Dampak Penerbitan Sukuk Terhadap Kinerja Bank Syariah (Studi Kasus Pada PT Bank Syariah Mandiri). Tesis Universitas Indonesia.

Al Quran dan Terjemahan.
Anshori, Muslich dan Sri Iswati. 2009. Metode Penelitian Kuantitatif. Surabaya: Pusat Penerbitan dan Percetakan UNAIR.

Baynuny, F. Ahmad. 2013. Pengaruh Sukuk Terhadap Profitabilitas dan Nilai Perusahaan Emiten (Studi Kasus 2007-2011). Skripsi Universitas Islam Negeri Sunan Kalijaga Jogjakarta.

Brealley, A. Richard and Myers, S.C. 2000. Principles of Corporate Finance. Internasional Edition. Mc Grow Hill.

Brigham, F. Eugene and Ehrhardt, C. Michael. 2001. Financial Management. Tenth Edition. Harcourt.

Brigham, F. Eugene and Joel F. Housten. 2004. Dasar-Dasar Manajemen Kevangan. Terjemahan oleh Ali Akbar Yulianto. Jakarta: Salemba Empat.

Copeland,TE, and JF Weston. 1994. Financial Theory and Corporate Policy. 3th edition. New York: Pearson Addison Wesley.

Darsono dan Ratri Dian H. 2012. Pengaruh Karakteristik Perusahaan Terhadap Struktur Modal Perusahaan Manufaktur yang Terdaftar pada Bursa Efek Indonesia. Volume1, No.1. Diponegoro Journal of Accounting.

Fatwa Dewan Syariah Nasional No.7/DSNMUI/IV/2000 Tentang Pembiayaan Mudharabah.

Fatwa Dewan Syariah Nasional No.32/DSN-MUI/IX/2002 Tentang Obligasi Syariah.

Fatwa Dewan Syariah Nasional No.33/DSN-MUI/IX/2002 Tentang Obligasi Syariah Sukuk Mudharabah.

Fatwa Dewan Syariah Nasional No.41/DSN-MUI/III/2004 Tentang Obligasi Syariah Sukuk ljarah.

Gujarati, Damodar N dan Dawn C. Porter. 2013. Dasar-Dasar Ekonometrika. 
Fakhrana, et al/Jurnal Ekonomi Syariah Teori dan Terapan Vol. 5 No. 5 Mei 2018: 405-419;

PENGARUH PENERBITAN SUKUK TERHADAP RETURN ON ASSETS EMITEN DI BURSA EFEK INDONESIA.

Edisi 5 Buku 2. Jakarta: Salemba Empat.

Helfert, Erich A. 2003. Techniqques Of Financial Analysis. Seventh Edition. Boston: Richard D Irwin.

Huda, Nurul dan Mustafa Edwin Nasution. 2007. Investasi pada Pasar Modal Syariah. Jakarta: Kencana Prenada Media Group.

Husnan, Suad. 2001. Dasar-dasar Teori Portofolio dan Analisis Sekuritas. Edisi ketiga. Jogjakarta: UPP SMP YKPN.

Herlambang, Leo. 2014. Struktur Keuangan Islami, Kinerja Kevangan dan Kinerja Pasar Saham (Studi Pada Emiten Saham Syariah Indonesia). Disertasi Thesis Tidak Diterbitkan. Universitas Airlangga.

Jones, Charles P. 2002. Investment: Analysis and Management. Eight Edition. John Willey \& Sons Inc.

Julita. 2010. Pengaruh Debt To Equity Ratio Dan Debt To Assets Ratio Terhadap Profitabilitas Pada Perusahaan Transformasi Yang Terdaftar Di Bursa Efek Indonesia. Vol 1, No 1. Universitas Muhammadiyah Sumatera Utara.

Kasmir. 2010. Analisis Laporan Keuangan. Cetakan Ketiga. Jakarta: Raja Grafindo Persada.

Madura, Jeff. 2009. Pengantar Bisnis. Edisi Keempat. Buku 2. Jakarta: Salemba Empat.

Mujahid, dan Tettet Fitrijanti. 2010. Pengaruh Penerbitan Obligasi Syariah (Sukuk) Perusahaan Terhadap Reaksi Pasar. SNA XIII. Universitas Jendral Soedirman Purwokerto.
Namora. 2006. Perbandingan Market Performance dan Karakteristik Keuangan Perusahaan Sektor Aneka Industri dengan Sektor Properti Real-Estate. Program Studi Manajemen Program Pasca Sarjana Universitas Pelita Harapan. Jakarta.

Otoritas Jasa Keuangan. 2017. Statistik Sukuk Korporasi di Indonesia (Sumber:

http://www.ojk.go.id/id/kanal/syari ah/data-dan-statistik/data-produkobligasi-syariah/Pages/Statistik-

Sukuk-Desember-2015.aspx) diakses pada tanggal 24 Januari 2017.

Putri, R. Ajeng Ardiyanti. 2015. Pengaruh Penerbitan Sukuk ljarah Terhadap Kinerja Keuangan Emiten di Bursa Efek Indonesia Tahun 2009-2013. Skripsi Tidak Diterbitkan. Universitas Airlangga.

Rahardjo, Budi. 2009. Dasar-dasar Analisis Fundamental Saham: Laporan Keuangan Perusahaan. Yogyakarta: Gadjah Mada University Press.

Ramadhani, Ikromi. 2010. Pengaruh Penerbitan Obligasi Syariah Pada Profitabilitas (Studi Pada Perusahaan-Perusahaan Yang Menerbitkan Obligasi Syariah di BEI (Bursa Efek Indonesia) Tahun 20042009). Skripsi Universitas Islam Negeri Syarief Hidayatullah Jakarta.

Rosiyadi, Tatik. 2014. Analisis Pengaruh Penerbitan Obligasi Syariah Terhadap Profitabilitas Perusahaan yang Menerbitkan Obligasi Syariah ljarah di Indonesia Tahun 20092012. Vol 3, No 2. Jurnal Kajian IImiah Akuntansi Fakultas Ekonomi UNTAN. 
Fakhrana, et al/Jurnal Ekonomi Syariah Teori dan Terapan Vol. 5 No. 5 Mei 2018: 405-419;

PENGARUH PENERBITAN SUKUK TERHADAP RETURN ON ASSETS EMITEN DI BURSA EFEK INDONESIA.

Ross, Westerfield, and Jeff. 2005. Corporate Finance. Seventh Edition. New York: Irvin Mc Grow Hill.

Ryandono, M. Nafik Hadi. 2009. Bursa Efek dan Investasi Syariah. Jakarta: Serambi.

Shyam, Sunder,L., and Myers,S.C. 1999. Testing Statistic Trade Off Againts Pecking Order Model Of Structure. Journal of Financial Ekconomics,51:219-244.

Sudana, I Made. 2009. Manajemen Keuangan Teori dan Praktik. Surabaya: Airlangga University Press.

Sugiyono. 2012. Metode Penelitian Kuantitatif, Kualitatif dan R\&D. Bandung: Alfabeta.

--. 2013. Metode Penelitian Bisnis (Pendekatan Kuantitatif, Kualitatif dan $R \& D)$. Bandung: Alfabeta.

Sukmaningrum, Puji Sucia. 2009. Reaksi Pasar Terhadap Pengumuman Penerbitan Obligasi Syariah di Bursa Efek Indonesia. Skripsi Tidak Diterbitkan. Universitas Airlangga.

Sunariyah. 2011. Pengantar Pengetahuan Pasar Modal. Edisi keenam. Yogyakarta: Sekolah Tinggi IImu Manajemen YKPN.

Suta, I Putu Gede Ary. 2005. Kinerja Pasar Perusahaan Publik di Indonesia: Suatu Analisis Reputasi Perusahaan. Jakarta: Yayasan SAD Satria Bhakti.

Sutedi, Adrian. 2011. Pasar Modal Syariah, Sarana Investasi Keuangan Berdasarkan Prinsip Syariah. Jakarta: Sinar Grafika.

Tandelin, Eduardus. 2001. Analisis Investasi Dan Manajemen Portofolio. Yogyakarta. BPFE Yogyakarta.
Tunggal, Amin Widjaja. 2008. Audit Manajemen. Jakarta: Rineka Cipta.762-786.

Umar, Husein. 2001. Metodologi Penelitian, Aplikasi dalam Pemasaran. PT Gramedia Pustaka Utama: Jakarta.

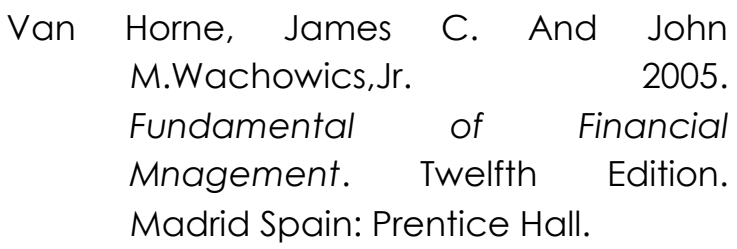

Universitas Airlangga. 2009. Pedoman Penulisan Pembimbingan dan Ujian Skripsi. Surabaya: Airlangga University Press.

Widarjono, Agus. 2010. Analisis Statistika Multivariat Terapan. Yogyakarta: UPP STIM YKPN -. 2013. Ekonometrika (Pengantar dan Aplikasinya). Edisi Keempat. Yogyakarta: UPP STIM YKPN.

www.cnnindonesia.com update tanggal 22 November 2016

www.idx.co.id 